Original Research Article

\title{
Drug schedules: knowledge among undergraduate medical students in a government medical college in Eastern India
}

\author{
Tania Sur' ${ }^{1}$, Parama Sengupta ${ }^{1 *}$, Ananya Mandal' ${ }^{2}$, Nina Das ${ }^{1}$
}

\begin{abstract}
${ }^{1}$ Department of Pharmacology, Nil Ratan Sircar (NRS) Medical College, Kolkata, West Bengal, India

${ }^{2}$ Department of Pharmacology, Bankura Sammilani Medical College, Bankura, West Bengal, India
\end{abstract}

Received: 14 June 2017

Accepted: 19 June 2017

*Correspondence to:

Dr. Parama Sengupta,

Email: paramas82@gmail.com

Copyright: (C) the author(s), publisher and licensee Medip Academy. This is an openaccess article distributed under the terms of the Creative Commons Attribution NonCommercial License, which permits unrestricted noncommercial use, distribution, and reproduction in any medium, provided the original work is properly cited.

\begin{abstract}
Background: In India many of the prescription only drugs (Schedule H) are available without prescription, leading to injudicious use, incidences of dangerous drug interactions, and unnecessary economic burden. Thus awareness among healthcare professionals and among common public are equally important. Objective was to assess the knowledge among undergraduate medical students in a government medical college in Eastern India regarding drug schedules in India.

Methods: Willing $3^{\text {rd }}$ semester and $5^{\text {th }}$ semester students participated in the study. We used a pre-tested validated two-part questionnaire to assess the knowledge of undergraduate medical students regarding different drug schedules.

Results: $5^{\text {th }}$ semester students gave significantly higher correct answers $(\mathrm{P}<0.0001)$ regarding awareness about Drugs and Cosmetics Act 1940, different drug schedules in India, expiry period, guidelines for maintaining the details of standards for patent and proprietary medicines, guidelines regarding import and manufacture of new drugs, guidelines regarding import and manufacture of new drugs, any special license is required for the manufacture and sale of psychotropic drugs, drugs marketed only under "generic name", guideline regarding pack size of drugs, and guidelines regarding good manufacturing practice (GMP)?. Analysis of second set of questionnaires revealed that the 5th semester students identified the different drug categories more correctly compared to the 3rd semester students.

Conclusions: Doctors are one of the principle and reliable sources of drug information for the general population. Thus, it becomes relevant that the undergraduate medical students should regularly brush up their knowledge regarding drug regulations even after passing Pharmacology examination in the later years of training.
\end{abstract}

Keywords: Drug schedules, Drugs and cosmetics act 1940, Schedule H drugs, Undergraduate medical students

\section{INTRODUCTION}

In India different drugs are categorized under different schedules under the Drugs and Cosmetics Act 1940 and the Drugs and Cosmetics Rule 1945. ${ }^{1}$ The parliament of India passed the Drugs and Cosmetics Rules, 1945 to categorize different drugs under different schedules; the said rule also provides guideline for storage, sale, display, and prescription of drugs categorized under the different schedules. $^{1,2}$ The principal objective of this act is to ensure safety, effectiveness, and maintenance of standard quality of the rugs and cosmetic products sold in India. ${ }^{2-4}$

There are schedules some of which like schedule $\mathrm{F}$ and schedule $\mathrm{P}$ has subcategorization, schedule FI, FII, and FIII and schedule PI, respectively. ${ }^{2}$ Different schedules under the Drugs and Cosmetics Rules, 1945, include Schedule A, Schedule B, Schedule C, Schedule E, Schedule F, Schedule F-F, Schedule G, Schedule H, Schedule J, Schedule K, Schedule M, Schedule N, Schedule O, Schedule P, Schedule Q, Schedule R, 
Schedule S, Schedule T, Schedule U, Schedule V, Schedule Y, and Schedule X. Among all these schedules four schedules deserve separate mentioning; these are Schedule H, Schedule X, Schedule J, and Schedule G. ${ }^{2}$

Schedule $\mathrm{H}$ includes drugs which can only be sold with a prescription of a registered medical practitioner and only in the amount specified in the prescription. ${ }^{2,5,6}$ Some of the Schedule $\mathrm{H}$ drugs might come under the purview of Narcotic Drugs and Psychotropic Substances Act, 1985; these drugs must carry texts "NRx" and "Schedule $\mathrm{H}$ drug" on the label. ${ }^{5-7}$ Like Schedule H, Schedule X drugs are also prescription drugs, however, in this case the retailer has to preserve the corresponding prescription for a minimum period of two years. ${ }^{8}$ Schedule $G$ drugs are usually the hormonal preparations, while Schedule J mentions various diseases and health related conditions which cannot be treated by any drug currently available in the market. ${ }^{2,8,9}$

Other than drugs various surgical and medical devices, bandages, surgical dressings, disinfectant fluids, mechanical contraceptives (condoms), vaccines, various Ayurvedic, Siddha, Unani products, etc. are also included in different schedules. ${ }^{2}$

In the US, drugs and other substances used to prepare drugs are categorized into five categories, namely Schedule I, Schedule II, Schedule III, Schedule IV, and Schedule V. ${ }^{10}$ Schedule I includes drugs with no current acceptable medical indication, high degree of abuse potential, and only used for research purpose. Schedule II, III, IV and V drugs have severe, moderate, low and minimum abuse potential, respectively. ${ }^{10}$ In the US, manufacture and sale of Over-The-Counter (OTC) drugs are regulated by the Food and Drug Administration (FDA). ${ }^{11}$ OTC drugs are used to treat conditions which usually do not require supervision of a healthcare professional and have already proven to be safe for selfmedication. Many of the drugs have been approved as OTC drug in lower strengths whereas higher strengths of the same drug would require prescription. ${ }^{11}$

In other countries like Canada, UK, there are separate regulations regarding prescription and OTC drugs. ${ }^{12,13}$

Doctors cannot deny their duty to aware the patients they are treating regarding the importance of prescription and judicious use of drugs both from medical and legal viewpoints (Drug Schedules). As in our country many of the prescription only drugs are easily available at medicine shops without prescription, thereby, making the situation quite unsafe with regard to abuse potential of the drug (if any), specific side-effects, hazardous drug interactions, etc.

Medical students are the future doctors of our society, so assessing their knowledge and attitude and by taking measures to improve same regarding prescription, use, and regulations of scheduled drugs we can also hope to improve general public awareness to some extent.

In this study we tried to assess the knowledge and perception among undergraduate medical students in a Government medical college in East India regarding schedule drugs.

\section{METHODS}

It was a cross-sectional and questionnaire based study and the students participated in this study anonymously.

\section{Study subjects}

All the students of the $3^{\text {rd }}$ Semester batch (240) of 201617 and the $5^{\text {th }}$ Semester (247) batch of 2015-16 of Nilratan Sircar Medical College, Kolkata, were informed about the study. The willing candidates after giving written consent ( 230 of $3^{\text {rd }}$ semester students) and ( 210 of $5^{\text {th }}$ Semester batch) participated in the study.

The study was conducted in November 2016 at Nilratan Sircar Medical College, West Bengal.

\section{Study tools}

We used a pre-tested validated questionnaire to assess the knowledge and perception of undergraduate medical students regarding different drug schedules. The questionnaire was validated by two senior pharmacologists who did not participated in the study. The questionnaire was pre-tested among BSc nursing students.

The questionnaire contained two parts; the first part contained ten (10) closed ended questions (the participants were to mark any of the following two alternatives, yes/no). The Second part of the questionnaire contained names of 30 drugs (brand name/generic name) and the participants were asked to categorize them under three categories namely, category A (drugs with high abuse potential; only available for research purpose), category B (drugs available only with prescription), and category $\mathrm{C}$ (Over-The -Counter drugs requiring no prescription).

The first set of questions intended to assess the knowledge and attitude of the students regarding the different drug schedules in India, whereas the second set of questions intended to assess the knowledge of the students regarding specific drugs.

\section{Analysis of data}

After collection of the data, we compiled the data on Microsoft Office Excel word spreadsheet (Microsoft office version 2010). Chi square test was applied. P value less than 0.05 was considered to be statistically significant. 


\section{RESULTS}

Analysis of the demographic profile of the students revealed that the means age of the students were 20.78 years for $3^{\text {rd }}$ semester students and 22.05 years for $5^{\text {th }}$ semester students (Table 1). Female: Male ratios for 3rd and 5th semester students were 9:14 and 5:9, respectively (Table 1).

Analysis of the first set of questions revealed that most of the students of the $3^{\text {rd }}$ semester batch (180 out of 230) gathered drug related information from sources other than literature like from relatives, peers and media (either electronic or print); only 50 out of 230 students stated that literature was the principal source of drug information for them. However, students of the $5^{\text {th }}$ semester batch mostly (200 out of 210 students) acknowledged literature (books/pamphlets/package inserts) as their principal source of knowledge regarding drug information (Table 1).

\section{Table 1: Demographic profile of the participating students.}

\begin{tabular}{|lll|}
\hline & $3^{\text {rd }}$ semester & $\mathbf{5}^{\text {th }}$ semester \\
\hline Mean age (years) & 20.78 & 22.05 \\
\hline Female:Male & $9: 14$ & $5: 9$ \\
\hline $\begin{array}{l}\text { Source of drug } \\
\text { information (literature; } \\
\text { others) }\end{array}$ & $180 ; 50$ & $200 ; 10$ \\
\hline
\end{tabular}

Few of the students of $3^{\text {rd }}$ semester batch $(65$ and 87 students out of 230 , respectively) and most of the $5^{\text {th }}$ semester (190 and 185 students out of 210 students, respectively) knew about Drugs and Cosmetics Act 1940 $(\mathrm{P}<0.0001)$ and different drug schedules in India $(\mathrm{P}<0.0001)$ (Table 2).

Table 2: Comparison of correct responses of students regarding $1^{\text {st }}$ set of questionnaires; comparison done by chi square test.

\begin{tabular}{|c|c|c|c|}
\hline Questions & $3^{\text {rd }}$ Sem N=230 & $5^{\text {th }}$ Sem $\mathbf{N}=\mathbf{2 1 0}$ & P value \\
\hline & Correct & Correct & \\
\hline Are you aware of the Drug and Cosmetics acts Act 1940 & $65(71.73)$ & 190(90.47) & 0.0001 \\
\hline Are you aware of the different Schedules of drugs in India & $87(37.82)$ & $185(88.09)$ & 0.0001 \\
\hline Do all the drugs have expiry periods & $170(73.91)$ & 205(97.61) & 0.0001 \\
\hline $\begin{array}{l}\text { Are there guidelines for maintaining the details of standards for patent } \\
\text { and proprietary medicines }\end{array}$ & $107(46.52)$ & 199(94.7) & 0.0001 \\
\hline $\begin{array}{l}\text { Are there any guidelines regarding import and manufacture of new } \\
\text { drugs }\end{array}$ & $165(71.73)$ & $189(90)$ & 0.0001 \\
\hline Can drugs cure/prevent all diseases & $189(43.47)$ & $195(92.85)$ & 0.0008 \\
\hline $\begin{array}{l}\text { Do you know whether any special license is required for the } \\
\text { manufacture and sale of psychotropic drugs }\end{array}$ & $96(41.73)$ & $198(94.28)$ & 0.0001 \\
\hline Are there any drugs marketed only under "generic name" & $98(42.6)$ & 205(97.61) & 0.0001 \\
\hline Is there any guideline regarding pack size of drugs & $89(38.69)$ & $200(95.2)$ & 0.0001 \\
\hline $\begin{array}{l}\text { Are there any guidelines regarding good manufacturing practice } \\
\text { (GMP)? }\end{array}$ & $85(36.95)$ & $198(94.28)$ & 0.0001 \\
\hline
\end{tabular}

170 out of the $2303^{\text {rd }}$ semester students and 205 students out of $2105^{\text {th }}$ semester students knew that drugs have specific expiry dates $(\mathrm{P}<0.0001)$ (Table 2$)$. Regarding the existence of guidelines for maintaining standards for patent and proprietary medicines and guidelines importing and manufacturing new drugs, 107 and $1653^{\text {rd }}$ semester students, respectively, and 199 and $1895^{\text {th }}$ semester students, respectively, gave correct response $(\mathrm{P}<0.0001)$ (Table 2). $1893^{\text {rd }}$ semester students and 195 $5^{\text {th }}$ semester students knew that drugs cannot prevent/cure all diseases $(\mathrm{P}<0.0008)$ (Table 2). Regarding requirement of special license for manufacture and sale of psychotropic drugs, $963^{\text {rd }}$ semester students and $1985^{\text {th }}$ semester students gave correct response $(\mathrm{P}<0.0001)$ (Table 2). $983^{\text {rd }}$ semester students and $2055^{\text {th }}$ semester students correctly replied that there are drugs available in generic name $(\mathrm{P}<0.0001)$ and 89 and 200 students of $3^{\text {rd }}$ semester and $5^{\text {th }}$ semester students were aware of the facts that there are guidelines regarding pack size for $\operatorname{drugs}(\mathrm{P}<0.0001)($ Table 2).

Most of the $5^{\text {th }}$ semester students (198 students out of 210 students) were aware of Good Manufacturing (GMP) guidelines, however, only $853^{\text {rd }}$ semester students out of total 230 students knew about existence of GMP guidelines $(\mathrm{P}<0.0001)$ (Table 2$)$.

Analysis of the second set of questions revealed that majority of the $3^{\text {rd }}$ and $5^{\text {th }}$ semester students correctly identified the category A drugs ("Drugs with high abuse 
potential used only for research purpose) namely, LSD (66.67\% and $98.56 \%$, respectively), cocaine $(63.63 \%$ and 90.47, respectively), marijuana $(77.27 \%$ and $99.04 \%$, respectively) ecstasy ( $81.81 \%$ and $97.61 \%$, respectively), and heroin (90.09\% and $99.04 \%$, respectively) (Table 3).

Table 3: Comparison of responses of students regarding $2^{\text {nd }}$ set of questionnaires.

\begin{tabular}{|c|c|c|}
\hline Drugs & $\begin{array}{l}\text { Correct response } \\
\text { by } 3^{\text {rd }} \operatorname{Sem}(\%)\end{array}$ & $\begin{array}{l}\text { Correct response } \\
\text { by } 5^{\text {th }} \text { Sem }(\%)\end{array}$ \\
\hline Cocaine & 63.63 & 90.47 \\
\hline Marijuana & 77.27 & 99.04 \\
\hline Pan 40 & 22.72 & 70 \\
\hline Rantac & 22.72 & 68.95 \\
\hline Crocin & 75 & 90.47 \\
\hline Ecstasy & 81.81 & 97.61 \\
\hline Reglan & 13.63 & 91.9 \\
\hline Cetrizine & 9.09 & 76.19 \\
\hline Amphetamine & 59.09 & 81.41 \\
\hline Heroin & 90.09 & 99.04 \\
\hline Tramadol & 65.45 & 86.19 \\
\hline Savlon & 98.18 & 100 \\
\hline Vitamins & 98.18 & 100 \\
\hline Diazepam & 13.63 & 42.85 \\
\hline $\mathrm{OCP}$ & 22.72 & 47.61 \\
\hline Metrogyl & 14.09 & 46.66 \\
\hline Penicillin & 55 & 77.14 \\
\hline Insulin & 60 & 97.61 \\
\hline ORS & 86.36 & 95.2 \\
\hline Adrenaline & 67.27 & 87.61 \\
\hline Atropine & 55.36 & 84.14 \\
\hline Drugs & $\begin{array}{l}\text { Correct response } \\
\text { by } 3^{\text {rd }} \operatorname{Sem}(\%)\end{array}$ & $\begin{array}{l}\text { Correct response } \\
\text { by } 5^{\text {th }} \operatorname{Sem}(\%)\end{array}$ \\
\hline Chloroquine & 77.77 & 89.04 \\
\hline Amlodipine & 55.9 & 82.38 \\
\hline $\begin{array}{l}\text { Parenteral iron } \\
\text { preparations }\end{array}$ & 65.45 & 88.09 \\
\hline Lithium & 65.45 & 86.19 \\
\hline LSD & 66.67 & 98.56 \\
\hline Alprazolam & 45.76 & 85.67 \\
\hline Gelusil & 88.76 & 94.56 \\
\hline Morphine & 88 & 99 \\
\hline
\end{tabular}

They also correctly identified Gelusil (88.76\% and $94.56 \%$, respectively), crocin $(75 \%$ and $90.47 \%$, respectively), savlon $(98.18 \%$ and $100 \%$, respectively), vitamins $(98.18 \%$ and $100 \%)$, and oral rehydration salts (86.36\% and $95.2 \%$, respectively) as category $\mathrm{C}$ drugs ("Drugs available without prescription") (Table 3). Few of the $3^{\text {rd }}$ semester batch students in contrast to $5^{\text {th }}$ semester students correctly categorized category B drugs like alprazolam (45.76\% and $85.67 \%$, respectively), diazepam (13.63\% and $42.85 \%$, respectively), cetirizine (9.09\% and $76.19 \%$, respectively), Pan-40 (22.72\% and $70 \%$, respectively), oral contraceptive pills $(22.72 \%$ and $47.61 \%$, respectively), rantac $(22.72 \%$ and $68.95 \%$, respectively), reglan (13.63\% and $91.9 \%$, respectively) and metrogyl (14.09\% and $46.66 \%$, respectively), in category C) (Table 3).

However, many of the $3^{\text {rd }}$ semester students like $5^{\text {th }}$ semester students identified several category B drugs correctly; common correctly identified category B drugs are morphine (88\% and $99 \%$, respectively), adrenaline $(67.27 \%$, and $87.61 \%)$, atropine $(55.36 \%$, and $84.14 \%$, respectively), insulin (60\% and $97.61 \%$, respectively), penicillin (55\% and $77.14 \%$, respectively), amphetamine (59.09\% and $81.41 \%$, respectively), tramadol $(65.45 \%$ and $86.19 \%$, respectively), amlodipine $(55.9 \%$ and $82.38 \%$, respectively), chloroquine $(77.77 \%$ and $89.04 \%$, respectively), parenteral iron preparations $(65.45 \%$ and $88.09 \%$, respectively), and lithium $(65.45 \%$ and $86.19 \%$, respectively) )(Table 3 ).

\section{DISCUSSION}

Currently in India people can buy majority of the drugs available in market without any prescription. Although there are several benefits of appropriate self-medication, like better access to drugs and immediate relief for patients, active participation of patients in his or her own health care, less burden on physicians because of adequate management of minor health related issues, etc., self-medication cannot be considered as a safe practice because of potential risks of inappropriate diagnosis, unnecessary delay in seeking appropriate medical advice, severe form of adverse drug reaction or drug-drug interactions, inappropriate choice of drug, and dosage schedule, masking of important symptoms of underlying serious diseases, risk of emergence of drug resistance, dependence and even abuse. ${ }^{14}$

Thus the authorities in different countries including India have categorized drugs under different schedules which specifically describe which of the currently marketed drugs are available without prescription (OTC drugs) and which of the drugs are only available with a prescription. ${ }^{2}$ This step helps the general population to treat minor ailments on their own with the help of the OTC drugs, however, at the same time restricts indiscriminate use of certain drugs which might cause severe Adverse Drug Reactions (ADRs), drug-drug interactions or require physician's supervision.

As with general population self-medication is also quite common among undergraduate medical student. ${ }^{15-17}$ However, unlike general people, the chance of appropriate self-medication is better among medical students for obvious reasons. ${ }^{18}$

Besides knowledge of drugs pertaining to Pharmacology, the medical students should also be aware of the different drug schedules prevalent in India. To the best of our knowledge ours is the first study to explore the knowledge and perception of undergraduate basic 
medical students regarding the different drug schedules in India.

Analysis of the results reveal that the $5^{\text {th }}$ semester students, who have completed Pharmacology course performed better in comparison to their $3^{\text {rd }}$ semester counterparts who have just started Pharmacology course.

As per Table 2, students of the $5^{\text {th }}$ semester students were significantly better aware $(\mathrm{P}<0.05)$ compared to the $3^{\text {rd }}$ semester students regarding knowledge about Drugs and Cosmetics acts Act 1940 ( $\mathrm{P}<0.0001)$, different Schedules of drugs in India ( $\mathrm{P}<0.0001)$, expiry periods ( $\mathrm{P}<0.0001)$, guidelines for maintaining the details of standards for patent and proprietary medicines $(\mathrm{P}<0.0001)$, guidelines regarding import and manufacture of new drugs $(\mathrm{P}<0.0001)$, requirement of special license for the manufacture and sale of psychotropic drugs ( $\mathrm{P}<0.0001)$, availability of generic drugs $(\mathrm{P}<0.0001)$, guideline regarding pack size of drugs $(\mathrm{P}<0.0001)$, and guidelines regarding good manufacturing practice (GMP) (P $<0.0001)$.

Again, Table 3 represent, how correctly students of the two batches $3^{\text {rd }}$ and $5^{\text {th }}$ semester batches responded. Most of the $3^{\text {rd }}$ and $5^{\text {th }}$ semester students identified the category A drugs namely LSD, cocaine, marijuana, ecstasy, and heroin and category C drugs (OTC drugs) namely, Gelusil, crocin, savlon, vitamins, and oral rehydration salts.

But in contrast to these two categories, most of the $3^{\text {rd }}$ semester students could not identify many of the category B drugs namely alprazolam, diazepam, cetirizine, Pan-40, oral contraceptive pills, rantac, reglan and metrogyl, except for the following drugs morphine, adrenaline, atropine, insulin, penicillin, amphetamine, tramadol, amlodipine, chloroquine, parenteral iron preparations, and lithium (Table 3).

Thus it can be concluded that in our institution $5^{\text {th }}$ semester students of the batch 2015-16 are comparatively more aware than $3^{\text {rd }}$ semester students of the batch 201617 , regarding different drug related regulations and also about the OTC drugs and prescription drugs. However, not all the students of the $5^{\text {th }}$ semester responded correctly implying that there remains a gap in the knowledge even after studying Pharmacology for one and half years.

Knowledge of different drug categories and drug regulations are very important as knowing the different drug categories will reduce self-administration of prescription drugs and at the same time make the general population aware of the safe OTC drugs. Doctors are one of the principle and reliable sources of drug information for the general population. Thus it becomes relevant that the students should regularly brush up their knowledge regarding drug regulations even after passing Pharmacology examination in the later years of training.
Funding: No funding sources

Conflict of interest: None declared

Ethical approval: The study was approved by the Institutional Ethics Committee

\section{REFERENCES}

1. Drugs and Cosmetics Act, 1940. (PDF). Central Drugs Standard Control Organization. Retrieved 19 February 2015.

2. Drugs and Cosmetics Act, 1940. (PDF). Central Drugs Standard Control Organization. Retrieved 23 February 2017.

3. Srivastava, Lila. Law and Medicine. $2^{\text {nd }}$ Ed., Universal Law Publishing, 2015

4. Malik, Vijay. Law Relating to Drugs and Cosmetics, $24^{\text {th }}$ Ed., Lucknow: Eastern Book Company; 2014.

5. Functions undertaken by Central/State Government. CDSCO, Directorate General of Health Services, Ministry of Health and Family Welfare, GoI. Archived from the original on 29 January 2011. Retrieved 23 February 2017.

6. Drugs and Cosmetics ( $2^{\text {nd }}$ Amendment) Rules, (PDF). Department of Health. New Delhi: Ministry of Health and Family Welfare of GoI in The Gazette of India (extraordinary) Part-II, section 3, sub-section (i) vide G.S.R. 160(E), dated 16 ${ }^{\text {th }}$ March, 2006. 16 March 2006. Archived from the original (PDF) on 21 February 2007. Retrieved 23 February 2017

7. The Narcotic Drugs and Psychotropic Substances Act, 1985. Retrieved May 23, 2017. Available at: http://cbn.nic.in/html/ndpsact1985.pdf.

8. National Formulary of India (NFI) 2011-Central Drugs Standards Control Organization. Retrieved May 23, 2017. Available at: http://www.cdsco.nic.in/writereaddata/NFI_2011\%20 (1).pdf.

9. Guharaj PV. Forensic Medicine. Orient Blackswan. Retrieved 23 February 2017; 2003:327.

10. Federal Food, Drug, and Cosmetic Act. U.S. Food and Drug Administration. Retrieved on 24 February 2017.

11. Mahecha LA. Rx-to-OTC switches: trends and factors underlying success. Nat Rev Drug Discov. 2006;5:380-5.

12. National Drug Schedules - Overview. National Association of Pharmacy Regulatory Authorities. Retrieved 26 February 2017.

13. Webb DJ. UK medicines policy: The role of clinical pharmacologists. $\mathrm{Br} \mathrm{J}$ Clin Pharmacol. 2012 Jun;73(6):948-52.

14. Ruiz ME. Risks of self-medication practices. Curr Drug Saf. 2010;5:315-23.

15. Bang S, Sontakke S, Thawani V. Pre and postinterventional pattern of self medication in three common illnesses in staff of a tertiary hospital. Indian J Pharmacol. 2011;43:275-7.

16. Kumar N, Kanchan T, Unnikrishnan B, Rekha T, Mithra P, Kulkarni V, et al. Perceptions and practices 
of self-medication among medical students in coastal South India. PLoS One. 2013;8:e72247.

17. Banerjee I, Bhadury T. Self-medication practice among undergraduate medical students in a tertiary care medical college, West Bengal. J Postgrad Med. 2012;58:127-31.

18. Sharma A, Oommen S, Topno I, Saya RP. Perceptions and practices of self-medication in healthcare and nonhealthcare university students in
South India. J Basic Clin Physiol Pharmacol. 2015;26:633-40.

Cite this article as: Sur T, Sengupta P, Mandal A, Das N. Drug schedules: knowledge among undergraduate medical students in a government medical college in Eastern India. Int J Basic Clin Pharmacol 2017;6:1625-30. 